\title{
Kovid-19 Salgını Sürecinde Özel Gereksinimli Çocukları Olan Ebeveynlerin İhtiyaçları ${ }^{1}$
}

\author{
Arş. Gör. Şeyda YILDIRIM-PARLAK* \\ Hasan Kalyoncu Üniversitesi, Eğitim Fakültesi, Özel Eğitim Bölümü, Gaziantep / Türkiye, \\ seyda.yildirim@hku.edu.tr, ORCID: 0000-0002-1139-2447 \\ Arş. Gör. Sevim KARAHAN \\ Hasan Kalyoncu Üniversitesi, Eğitim Fakültesi, Özel Eğitim Bölümü, Gaziantep / Türkiye, \\ sevim.karahan@hku.edu.tr, ORCID: 0000-0001-7753-4105 \\ Arş. Gör. Kübra DEMIRÖZ \\ Hasan Kalyoncu Üniversitesi, Eğitim Fakültesi, Özel Eğitim Bölümü, Gaziantep / Türkiye, \\ kubra.ozgan@hku.edu.tr, ORCID: 0000-0002-6054-0901 \\ Doç. Dr. Latife ÖZAYDIN \\ Özel Eğitim Uygulama ve Araştırma Merkezi, Gaziantep / Türkiye \\ latife.ozaydin@hku.edu.tr, ORCID: 0000-0002-2975-1620
}

\section{$\ddot{\mathbf{O} z}$}

Bu çalışma Gaziantep ilinde karantina günlerini 2-20 yaş arasındaki özel gereksinimli çocuklarıyla birlikte evlerinde geçiren ebeveynlerin ihtiyaçlarını ve sunulan hizmetler hakkındaki görüşlerini belirlemeyi amaçlamıştır. Salgın tüm dünya ülkelerini etkileyen küresel bir krize dönüşmüştür. Çalışma, nitel araştırma yaklaşımı çerçevesinde

\footnotetext{
${ }^{1} \mathrm{Bu}$ çalışma, 21-23 Haziran 2020 tarihleri arasında düzenlenen International Conference on Covid-19 Studies Kongresinde sözlü bildiri olarak sunulmuştur.

* Sorumlu Yazar. Tel: +90 (342) 2118080 | Araştırma Makalesi.

Makale Tarih Bilgisi. Gönderim: 21.12.2020, Kabûl: 13.03.2021, Erken Görünüm: 13.07.2021, Basım: Haziran, 2022

(C) 2022. Kalem Eğitim ve Sağlık Hizmetleri Vakfı. Bütün Hakları Saklıdır. ISSN: 2146-5606, e-ISSN: 2687-6574.
} 
olgu bilim (fenomenoloji) deseni ile yürütülmüştür. Çalışmanın katılımcıları, kolay ulaşı1ır durum örneklemesi yöntemi ile ilin öğrenci sayısı açısından en yoğun olduğu bir özel eğitim ve rehabilitasyon merkezine çocukları devam eden 273 ebeveyndir. Katılımcıların \%30'u bedensel yetersizliği, \% 25'i zihin yetersizliği ve \%16'sı otizm spektrum bozukluğu olan çocukların ebeveynleridir. Elde edilen veriler araştırma soruları ve betimsel analiz ile değerlendirilmiştir. Ebeveynlerin ihtiyaçlarının eğitim, sosyal ve psikolojik destek, çocuk bakım desteği, ekonomik destek, sağlık ve terapi hizmetleri olduğu görülmüştür. Bu süreçte ebeveynler, en çok özel eğitim öğretmenlerinin desteğine ihtiyaç duymuşlardır. Ebeveynlerin çoğu merkezde görevli özel eğitim öğretmenleri tarafından öğrencilerin bireysel ihtiyaçları doğrultusunda hazırlanan ödev ve etkinlikleri ve sosyal medya aracıllğıyla kendilerine sunulan eğitim paylaşımlarını yararlı bulmuşlardır.

Anahtar Kelimeler: Kovid-19; Çevrim içi; Aile ihtiyaçları; Olgu bilim; Özel gereksinimli çocuklar; Özel eğitim öğretmeni.

\title{
Needs of Parents with Special Needed Children During the Covid-19 Outbreak
}

\begin{abstract}
This study aimed to determine the needs of parents who spend their quarantine days in their homes with their special needed children between 2 and 20 years of age in Gaziantep, their needs and their views on the services provided. The epidemic has turned into a global crisis affecting all countries of the world. The study was conducted with a phenomenology design within the framework of qualitative research approach. The participants of the study were 273 parents representing the maximum diversity who received support education services from a special education and rehabilitation center for their children. $30 \%$ of the participants are the parents of children with physical disability, $25 \%$ with mental disability and $16 \%$ with autism spectrum disorder. The obtained data were evaluated with descriptive analysis in line with research questions and literature. It has been observed that the needs of the parents are education, social and psychological support, child care support, economic support, health and therapy services. In this process, parents most needed the support of special education teachers. Most of the parents found the homework and activities prepared by the special education teachers working in the center in line with the individual needs of the students useful through the virtual media. Keywords: Kovid-19; Online; Family Needs; Phenomenology; Children with special needs; Special education teacher.
\end{abstract}




\section{Extended Summary}

\section{Purpose}

Education is one of the fields that has been affected by Covid-19 pandemic. In this sense, school closures, cleaning, masks, and social distance measures have disrupted the habits of Children with Special Needs (SN) (Özaydın, 2020a; Toseeb, Asbury, Code, Fox and Deniz, 2020). This study aims to examine the needs of parents who spend their quarantine days at home with their children with SN and their opinions about the services provided. Identifying parents' needs and their views on online services will allow for the evaluation and further development of practices. Findings will provide us insight as to how children with SN and their parents can be supported at home during the lockdown.

\section{Method}

The phenomenology design, which adopts a qualitative research approach, was used in this study (Creswell and Plano-Clark, 2011; Y1ldırım and Şimşek, 2018). The participants of the study were 273 parents, including 208 mothers and 65 fathers with children between 2 and 20 years of age, who received support from a special education and rehabilitation center (SERC) in Gaziantep. An online interview form prepared with Google documents. It consists of a demographic information part about parents and their children and five interview questions for the parents to answer. After obtaining the necessary written and verbal consent for the study, the online form was shared with the families and one of the voluntary parents was asked to fill it in. Parents filled in the online form between 28/04/2020 and 20/05/2020. Parents' written responses were analyzed descriptively by creating a conceptual framework within the context of research questions and literature (Bailey, Blasco and Simeonsson, 1992; Yıldırım and Şimşek, 2018).

\section{Results}

Parents 'views were analyzed and categorized into four themes and subthemes: (1) Parents' views on the SERC services; (2) Professional staff needed by parents; (3) Parents' needs regarding their children with SN, and their families; (4) Parents' views and suggestions to meet their needs.

Parents found it useful for special education teachers to share homework and activities with them and to communicate once a week in line with their children's individual needs. Few parents stated that EBA is insufficient since it is based on one-way interaction and their children have difficulty in 
focusing. It was found that the pandemic increased the use of virtual media by the parents of children with SN. Also, the parents needed the opinions and the suggestions of special education teachers the most. The other required professional staff were physiotherapists, physical education and sports teacher, child psychiatrist, vocational lesson teacher, barbers, caregivers, and cleaning workers, respectively. Another finding was that the primary need of parents in this process is education. Parents reported that they need the education to support their children with SN and want to be included in their children's education processes. The secondary needs of the parents were found as social and psychological support, mostly because their social interactions with relatives, friends, and neighbors were limited and their responsibilities towards their children increased. The findings also revealed that mothers needed childcare support including hourly or day-long service for the safety, care, and education of their children. While mothers mostly expressed their material needs for the education of their children, such as equipment and internet access; fathers stated that they needed economic support to take care of their home and children.

In addition, parents' suggestions included the following; continuation of online education services offered by special education teachers and providing social and psychological support for themselves and their children. Mothers suggested that schools should be opened as soon as possible in accordance with social distance rules and that telehealth services should become more widespread.

\section{Discussion}

The study revealed the needs of the parents who have children with SN and have to stay home due to lockdown caused by Covid-19. These needs include educational, social, and psychological support from the professionals as well as child care services and financial support. While most of the parents found the opportunity to meet with special education teachers once a week useful, a small number of parents found EBA insufficient due to their children's attention and focus difficulties. It is emphasized in many studies that EBA should be renewed in terms of quality and quantity for students with SN (Can, 2020; Karahan, Demiröz, Yıldırım and Özaydın, 2020; Y1lmaz, Mutlu and Doğanay, 2020). Parents' most primary needs are the education of their children and their own education for their children. Also, it was found that they needed special education teachers who know their children, know their 
characteristics, and offer more authentic activities. (Asbury, Fox, Deniz, Code and Toseeb, 2020; Toseeb et al., 2020). Another striking finding of the study is the social and psychological support needs of mothers. With the closure of schools, many services that children benefit from have been interrupted, and mothers' limitation of interaction with their relatives and friends has increased their anxiety. Therefore their need for psychological support has increased (Başaran and Aksoy, 2020; Drogomyretska, Fox and Colbert, 2020; Manning, Billian-Matson, Allen and Soares, 2020). Considering that $49.6 \%$ of the care and responsibility of children with $\mathrm{SN}$ is with mothers in our country (TUIK, 2010), it is important to provide social and psychological support as soon as possible for the sake of children and mothers. Another interesting finding of this study is that mothers need child care support, which is supported by the literature as well. The need of parents of children with SN and especially children with ASD for health services and home care support is universal (BurtonSmith, McVilly, Yazbeck, Parmenter ve Tsutsui, 2009; Colizzi, Sironi, Antonini, Ciceri, Bovo and Zoccante, 2020; Den Houting, 2020; Özaydın, 2020b; Toseeb et al., 2020; Yıldırım and Hacıfazlıoğlu, 2019). Financial needs ranked fourth among the needs of parents. Mothers stated that they mostly need material support for the education of their children, while fathers stated that they needed financial support for food and basic needs of their children. In our country, it is seen that usually, mothers take the responsibility for children with SN, while fathers are responsible for providing financial support to meet the needs of the family (Demirbilek, 2013; Gören, 2015; Turan-Gürhopur and İşler-Dalgıç, 2017). Research has shown that parents need financial support during the pandemic (Cluver et al., 2020; Lee, 2020; Manning et al., 2020), especially those whose income is reduced due to part-time work or layoffs. (Colizzi et al., 2020).

\section{Conclusion}

During the quarantine days, parents needed information to help their children adjust to changing routines, involve them in learning environments, and support their development. The findings revealed that they made use of online systems but preferred to be informed by special education teachers, with whom they communicate one-on-one. Another finding was that mothers needed partial or full-time support personnel such as caregivers and barbers, as the care and education responsibilities of children are mostly undertaken by mothers. Moreover, there is a need to bring flexibility to the use of parks, walking paths, and sports centers for children with $\mathrm{SN}$, and to make telehealth 
services widespread for the health and therapy needs of parents and children.

\section{Giriş}

Dünyayı etkisi altına alan Kovid-19 salgınının en belirgin izleri eğitim sektöründe yaşanmıştır. Salgının yayılmasını önlemek için alınan ilk tedbirler arasında birçok ülkede olduğu gibi Türkiye'de de okullar kapatılmış ve yüz yüze eğitime ara verilmiştir. Bu durum, milyonlarca öğrencinin ne zaman sona ereceği bilinmeyen bir süreci evlerinde geçirmeye başlamalarına neden olmuştur. Okulların kapatılması; temizlik, maske ve sosyal mesafe tedbirleri her bir ferdin sağlığını korumak için atılan kritik adımlar olsa da bu değişiklikler özel gereksinim (ÖG)'li çocukların alışkanlıklarını bozmuştur. Ani gelişen bu değişime tanıklık eden ebeveynler, çocuklarının günlük rutinlerinin değiştiğini, problem davranışlarının daha sık ve yoğun olduğunu (Colizzi, Sironi, Antonini, Ciceri, Bovo ve Zoccante, 2020) ve hareketlerinin ev ortamiyla k1sıtlandığını dile getirmişlerdir (Cacioppo ve ark., 2021; Narzisi, 2020; Özaydın, 2020a; Toy ve Kesici, 2020). Fiziksel sınırlamalar gibi öğretmenleri ve akranlarından uzak kalan çocukların sosyal rutinlerinin de değişmesiyle kaygı ve streslerinin arttığı görülmüştür (Den Houting, 2020; Lee, 2020; Pavlopoulou, Wood ve Papadopoulos, 2020; Wigg, Coutinho, Silva ve Lopes, 2020). Ülkemiz ilk kez koronavirüs salgınının yaygın etkisiyle karşılaşmış olsa da araştırmalar Ebola ve SARS salgınının yaygınlaşmasını önlemek için alınan izolasyon tedbirlerinin ÖG'li bireylerde ağır depresyona ve ciddi ruh sağlığı sorunlarına neden olduğunu göstermiştir (Den Houting, 2020; Jalloh ve ark., 2018).

ÖG'li çocukların yanı sıra sosyal izolasyon tedbirleri nedeniyle arkadaş ve akraba gibi sosyal desteklerini kaybeden, değişen çalışma koşulları nedeniyle maddi kayıplar yaşayan ebeveynlerin de kaygılarının arttığı, kendilerini yalnız ve dışlanmış hissettikleri görülmüştür (Asbury, Fox, Deniz, Code ve Toseeb, 2020; Marchetti, Fontanesi, Mazza, DiGiandomenico, Roma ve Verrocchio, 2020; Witt, Ordóñez, Martin, Vitiello ve Fegert, 2020). Bu araştırma bulgularının aksine salgının ailelerinin ruh sağlı̆g üzerinde olumsuz etkisi olmadığını hatta sürecin aile üyelerini bir araya getirerek olumlu etkileşimlere yol açtığını bildiren araştırma bulgularına da rastlanmıştır (Cahapay, 2020; Guralnick, 2011; Majoko ve Dudu, 2020; Toseeb, Asbury, Code, Fox ve Deniz, 2020).

ÖG'li çocukların ebeveynlerinin en yoğun desteğe ihtiyaç duydukları alanın bilgi edinme ve dolayısıyla eğitim alanı olduğu bilinmektedir. 
Çocukların geniş bir dağılım gösteren yetersizlik türleri ve değişen ihtiyaçları (Cacioppo ve ark., 2021; Kayhan ve Özaydın, 2017; Kerem-Günel, 2020) ebeveynlerin bilgi edinme gereksinimlerinin süreklilik gösteren ve küresel bir ihtiyaç olduğunu kanıtlamaktadır (Bailey ve ark., 2006; Burton-Smith, McVilly, Yazbeck, Parmenter ve Tsutsui, 2009; Chen ve Simeonsson, 1994). Kovid-19 salgını, ebeveynlerin çocuklarının aksayan eğitimlerini nasıl karşılayacakları konusunda bilgi edinme ihtiyaçlarını ön plana çıkarmıştır (Asbury ve ark., 2020). Örneğin, Toseeb ve arkadaşları (2020), 5-18 yaşları arasında ÖG'li çocuğu olan 339 ebeveynin salgın günlerinde en çok özel eğitim uzmanı veya özel eğitim öğretmenlerine ihtiyaç duyduklarını tespit etmişlerdir. Ebeveynler çocuklarının gereksinimleri ve yeni rutinleri uygulama konusunda özel eğitim öğretmenlerinden güvenilir bilgi ve öneriler aldıklarını bildirmişlerdir. Ebeveynlerin ihtiyaç duydukları uzman personele ve hizmetlere erişimlerinin k1sıtlanması nedeniyle ÖG'li çocuklarının ihtiyaçlarını karşılamak için öğretmen, bakıcı veya hemşire rolünü üstlendikleri görülmüştür (Asbury ve ark., 2020; Neece, McIntyre ve Fenning, 2020; Toseeb ve ark., 2020; Türkiye İstatistik Kurumu [TÜİK], 2010). Alanyazında dikkat çeken iki çalışma, Otizm Spektrum Bozukluğu (OSB) olan çocuklarına evde eğitim veren Zimbabwe (Majoko ve Dudu, 2020) ve Filipinli (Cahapay, 2020) ebeveynlerin olumlu deneyimlere sahip olduklarını göstermiştir. Her iki çalışmada da ebeveynler evde çocuklarıyla daha fazla etkileşim fırsatı bulduklarını, ev ortamının sakin bir hayat tarzı sağladığını, çocuklarının stres ve kaygılarını azalttığını ifade etmişlerdir. Cahapay (2020), Filipinli ebeveynlerin kendi çocukları gibi çocuklara sahip ebeveynlerle bilgi alışverişi yaptıklarını belirtmiştir. Ebeveynlerin bilgi edinmede en güvenilir kaynaklarının aile üyeleri ve diğer deneyimli ebeveynler olduğu bilinmektedir (Guralnick ve Albertini, 2006; Narzisi, 2020). Bilgi edinmenin yanı sıra ebeveynlerin hem kendileri hem de çocukları için izleyebilecekleri video model ile hazırlanmış egzersiz programlarına da ihtiyaç duydukları görülmüştür (Atl1-Yılmaz ve Atl1, 2020; Ercan, Arman, Emiroğlu, Öztop ve Yalçın, 2020; Esentürk, 2020; Limbers, McCollum ve Greenwood, 2020).

Kovid-19 salgını; uzaktan, çevrim içi sistemlerin kullanımını yaygınlaştırmıştır. Salgının ilanı ile eş zamanlı olarak ulusal ve uluslararası birçok kurum ve kuruluşun, ebeveynlerin yeterliliklerini artırmaya ve ebeveynler arac1lığıyla ÖG'li çocukları desteklemeye yönelik bir dizi öneri, bildiri ve çevrim içi kaynağı yayınladıkları görülmüştür (Cluver ve ark., 2020; Narzisi, 2020; UNICEF, 2020; World Health Organization [WHO], 2020; Yarımkaya ve 
Esentürk, 2020). Ülkemizde salgının ilanından kısa bir süre sonra Milli Eğitim Bakanlığı (MEB), 23 Mart 2020 tarihinden itibaren TRT-EBA TV ile Eğitim Bilişim A $\breve{g}$ (EBA) üzerinden tüm öğrenciler için “uzaktan eğitim” derslerini ve "sanal sınıf” uygulamalarını başlatmıştır. MEB, Özel Eğitim ve Rehberlik Hizmetleri Genel Müdürlüğü ise ÖG’li öğrencilerin evde internet üzerinden izleyebilecekleri interaktif linkleri öğretmenleri aracılığıyla ebeveynlere duyurmuştur (Özaydın, 2020a). Çevrim içi kaynakları özel eğitim öğretmenlerinin de kullandığı görülmektedir. Genellikle öğretmenler, ebeveynler aracıl1ğıyla ÖG'li öğrencilerinin okul ortamından tamamen uzak kalmamaları adına günlük ödevler ve etkinlikler göndererek uzaktan eğitim desteği sunmuşlardır (Çakın ve Akyavuz, 2020; Karahan ve ark., 2020; Toseeb ve ark., 2020). Ebeveynler, uzaktan eğitim sürecinde öğretmenlerin bilgisayar ve internet erişimlerinin yeterli olduğunu, çocuklarının bilgisayar ve internete erişimlerinin s1nırlı olduğunu belirtmişlerdir (Can, 2020; Yılmaz, Mutlu ve Doğanay, 2020). EBA'da bulunan içerik ve uygulamaların ÖG'li öğrencilerin ihtiyaçlarını karş1lamadığı tespit edilmiştir (Can, 2020). Öte yandan salgının hayatımıza kazandırdığı tele-sağlık uygulamalarının gelecekte ÖG'li çocukların sağlık kontrollerinin yapılması, raporlarının oluşturulması gibi yüz yüze riskler taşıyan durumlarda ihtiyacı karşılayacağı görülmüştür (Di Carlo ve ark., 2020; Kerem-Günel, 2020).

$\mathrm{Bu}$ çalışma, salgının ilanının ardından uygulanan karantina günlerini çocuklarıyla birlikte evlerinde geçiren ebeveynlerin ihtiyaçlarını ve kendilerine kısa sürede ulaşan hizmetler hakkındaki görüşlerini belirlemek ve ne zaman sona ereceği belli olmayan salgın sürecinde nasıl desteklenebileceklerine ilişkin öneriler açısından önemlidir. Çalışmanın bulguları salgının ilk iki ayına ilişkin ebeveynlerin algılarını yansıtmaktadır. Bulgular gelecekte herhangi bir nedenle olabilecek karantina günlerinde ÖG'li bireyleri ve ebeveynlerini destekleyecek müdahale programları hazırlamaya, politikalar oluşturmaya ve kamuoyunu bilgilendirmeye katkı sağlayacaktır. Ebeveynlerin görüşleri, karantina tedbirleri dolayısıyla çevrim içi anket görüşme formu ile salgının ilk günlerinde toplanmış ve geniş bir katılımcı grubunun görüşleri alınmıştır. Böylece farklı yetersizlik tanısı olan ÖG'li çocukların ebeveynlerinin görüşleri veri kaynağının zenginleşmesini sağlamıştır.

\section{Araştırmanın Amacı}

Bu çalışma ile Kovid-19 salgını sebebiyle karantinayı ÖG'li çocuklaryyla evde vakit geçiren ebeveynlerin ihtiyaçlarını belirlemek ve sunulan 
hizmetler hakkındaki görüşlerini tespit etmek amaçlanmıştır. Bu doğrultuda ÖG'li çocuğa sahip ebeveynlerin;

1. Sunulan hizmetler hakkındaki görüşleri nelerdir?

2. İhtiyaç duydukları meslek elemanları kimlerdir?

3. Çocuklarıyla ilgili ihtiyaçları nelerdir?

4. Kendileri ve aileleriyle ilgili ihtiyaçları nelerdir?

5. İhtiyaçlarının karşılanması yönündeki görüş ve önerileri nelerdir gibi sorulara yanıt aranmıştır.

\section{Araştırma Modeli}

\section{Yöntem}

Çalışmada ebeveynlerin ihtiyaçları ve sunulan hizmetler hakkındaki görüşlerini belirlemek için nitel araştırma yaklaşımı çerçevesinde olgu bilim (fenomenoloji) deseni kullanılmıştır (Creswell ve Plano-Clark, 2011).

\section{Çalışma Grubu}

Gaziantep ilindeki bir Özel Eğitim ve Rehabilitasyon Merkezinden (ÖERM) destek eğitim hizmeti alan çocukların ebeveynleri çalışma grubunu oluşturmaktadır. Bu merkezde ebeveynlere yönelik sunulan hizmetlerin iki türü olduğu görülmüştür: Birincisinde, merkeze devam eden öğrencilerin öğretmenleri tarafından ihtiyaçlarına yönelik olarak ebevynler ile ödev ve etkinlikler paylaşılmakla birlikte bir hafta sonrasında değerlendirilerek bildirimler verilmiştir. İkincisinde ise sosyal medyadan çocuklarının ve kendilerinin ihtiyaçları doğrultusunda ebeveynlere yönelik eğitim paylaşımları yapılmıştır.

Çalışmanın katılımcıları bu merkezden destek eğitim hizmeti alan, 220 yaşları arasında ÖG'li çocuğu olan 273 ebeveyndir. Katılımcıların belirlenmesinde amaçlı örneklem yöntemlerinden kolay ulaşılır durum örneklemi tekniği kullanılmıştır. Bu örnekleme yöntemi; araştırmaya hız ve pratiklik kazandıran bir teknik olması açısından salgın döneminde veri toplamaya firsat vermiştir. Özel eğitim merkezi Gaziantep'in iki merkez ilçesinden birinde en yoğun ve farklı yetersizlikteki öğrencilere hizmet veren bir kurum olması aç1sından istenilen öğrenci çeşitliliğine ulaşılmıştır. (Creswell ve Plano-Clark, 2011; Yıldırım ve Şimşek, 2018). Böylece, yaşları, eğitim düzeyleri ve mesleki bilgileri çeşitlilik gösteren 208 anne ve 65 baba çalışmanın katılımcıları olarak belirlenmiştir. Çocukların yetersizlik türleri hakkında kavramsal farkl11ıkları önlemek adına Özel Eğitim Hizmetleri Yönetmeliğinde (2018) 
kullanılan yetersizlik sınıflaması esas alınmıştır. Ebeveynlerin demografik bilgilerine Tablo 1'de, çocuklarının özelliklerine ise Tablo 2'de yer verilmiştir.

Tablo 1 incelendiğinde annelerin ve babaların yarıya yakını 26-35 yaş arasında iken diğerlerinin 36 yaş ve üzerinde olduğu görülmektedir. Eğitim durumu açısından annelerin çoğunluğunun $(\mathrm{n}=80)$ ilkokul mezunu, babaların ise lise mezunu $(n=37)$ olduğu görülmektedir. Annelerin büyük çoğunluğu (173) ev hanımı, diğerlerinin ise kamu $(n=24)$ ve özel sektörde $(n=11)$ çalıştığ görülmektedir. Babaların ise çoğunluğu $(n=35)$ özel sektörde, diğerleri ise kamu sektöründe $(\mathrm{n}=30)$ çalışmaktadır.

Tablo 1. Ebeveynlere İlişkin Demografik Bilgiler

\begin{tabular}{llllll}
\hline & Değişkenler & Anne & \multicolumn{3}{c}{ Baba } \\
\hline Yaş & & $\mathbf{n}$ & $\mathbf{\%}$ & $\mathbf{n}$ & $\mathbf{\%}$ \\
& $26-30$ & 34 & 16 & 7 & 11 \\
& $31-35$ & 61 & 29 & 22 & 34 \\
& $36-40$ & 34 & 16 & 22 & 34 \\
& $41+$ & 79 & 38 & 14 & 22 \\
\hline Ĕgitim & İlkokul & 80 & 39 & 12 & 19 \\
Durumu & Ortaokul & 35 & 17 & 6 & 9 \\
& Lise & 55 & 12 & 24 & 37 \\
& Ön lisans & - & - & 3 & 5 \\
& Lisans & 37 & 18 & 20 & 31 \\
\hline Meslek & Ev Hanımı & 173 & 83 & - & - \\
Bilgisi & Kamu Sektörü & 24 & 12 & 30 & 46 \\
& Özel Sektör & 11 & 5 & 35 & 54 \\
\hline
\end{tabular}

Ebeveynlerin ÖG'li çocuklarının \%32'si kız (n=87), \%68'i (n=186) erkek ve yaş ortalamaları 10'dur. Çocukların, Özel Eğitim Hizmetleri Yönetmeliğine (2018) göre yetersizlik türleri Tablo 2'de verilmiştir.

Tablo 2. Özel Gereksinimli Çocuklara İlişkin Demografik Bilgiler

\begin{tabular}{llll}
\hline & Değişkenler & $\mathbf{n}$ & $\mathbf{\%}$ \\
\hline Cinsiyet & Kız & 87 & 32 \\
& Erkek & 186 & 68 \\
\hline Yetersizlik & Bedensel Yetersizlik & 81 & 30 \\
Türü & Zihinsel Yetersizlik & 67 & 25 \\
& Otizm Spektrum Bozukluğu & 44 & 16 \\
& Görme Yetersizliği & 27 & 10 \\
& İşitme Yetersizliği & 26 & 10 \\
& Çoklu Yetersizlik & 16 & 6 \\
& Dil ve Konuşma Bozuklukları & 6 & 2 \\
& Dikkat Eksikliği HB. & 3 & 1 \\
& Gelişimsel Gerilik & 3 & 1 \\
\hline
\end{tabular}




\section{Veri Toplama Araçları, Verilerin Toplanması ve Analizi}

Ebeveynlerin ihtiyaçlarını ve bu sürede sunulan hizmetler hakkındaki görüşlerini belirlemek için "Google Dokümanlar" kullanılarak çevrim içi görüşme formu hazırlanmıştır. Çevrim içi görüşme formu ebeveynler ve çocukları hakkında demografik bilgilerin yer aldığı bir bölüm ile ebeveynlerin yazılı olarak yanıtlayacakları beş görüşme sorusundan oluşmuştur. Ebeveynler çevrim içi forma 28/04/2020-20/05/2020 tarihleri arasında yanıt vermişlerdir. İldeki ilgili üniversitenin Etik Kurulundan (E--804.01-2103010033) izin alındıktan sonra, ÖERM yetkilileri ile görüşülerek çalışma için yazılı ve sözlü izin alınıp çevrim içi formu aileler ile paylaşmaları ve gönüllü ebeveynlerden anne veya babanın birinin doldurması istenmiştir. Görüşme soruları ile ebeveynlerin; sunulan hizmetler, ihtiyaç duydukları meslek elemanları, çocukları, kendileri ve aile bireylerinin ihtiyaçları ve önerileri hakkındaki görüşleri belirlenerek çalımanın verileri toplanmıştır.

Ebeveynlerin çevrim içi forma verdikleri yazılı yanıtlar araştırmacılar tarafından okunmuş, araştırma soruları ve "Aile İhtiyaçları Anketi” bağlamında oluşturulan kavramsal bir çerçeveye göre betimsel analiz edilmiştir (Bailey, Blasco ve Simeonsson, 1992; Bailey ve Simeonsson, 2006; Yıldırım ve Şimşek, 2018). Ebeveynler, ihtiyaç duydukları meslek elemanlarına ilişkin yanıtlarını Sağlık Bakanlığı, MEB ve Aile, Çalışma ve Sosyal Hizmetler Bakanlığı bünyesinde yer alan kadrolar ve sosyal roller doğrultusunda oluşturulan 16 meslek elemanı veya roller (Aile hekimi, Çocuk Doktoru, Çocuk Nöroloğu, Fizyoterapist, Diş Hekimi, Hemşire, Çocuk Psikiyatristi, Psikolog, Sosyal Hizmet Uzmanı, Beden Eğitimi ve Spor Öğretmeni, Özel Eğitim Öğretmeni, Psikolojik Danışman, Meslek Dersi Öğretmeni, Deneyimli Ebeveyn, Din Görevlileri, Dernek/Vakıf Personeli vb.) arasından seçmişlerdir (Devlet Personel Başkanlığı, 2021).

\section{İnandırıcılık, Tutarlılık ve Teyit Edilebilirlik}

Araştırmacılar yüksek lisans ve doktora ders döneminde "Nitel Araştırmalar" dersini almışlar ve nitel araştırmalar yürütmüşlerdir (Kayhan ve Özaydın, 2017; Karahan ve ark., 2020; Özaydın, 2020b). Araştırmanın güvenirliğini sağlamak için görüşme sorularının oluşturulması, verilerin toplanması ve analizi aşamalarında uzman görüşleri alınmıştır. Özel eğitim alanında çalışan iki alan uzmanına görüşme soruları gönderilmiştir. Uzmanlardan gelen öneriler doğrultusunda soru maddeleri sadeleştirilerek görüşme sorularına sona hali verilmiştir. Görüşme dökümleri ve analizleri çalışmanın ilk üç yazarı 
tarafından yapılmış ve veriler kavramsal bir çerçeve ile sınıflandırılarak okuyucular için betimlenmiştir. Araştırma bulguları bir grup katılımcıyla yapılan telefon görüşmeleriyle teyit edilmiş, yazılı açıklamalarını destekleyen örnekleri paylaşmışlardır. Ebeveynlerin yapılan telefon görüşmelerinde ortaya ç1kan temaların kendi ihtiyaçları doğrultusunda örtüştügü görülmüştür. Ebeveyn katılımcılar amaçlı örneklem yöntemlerinden kolay ulaşılır durum örneklemesi yöntemi ile belirlenmiştir. Kovid-19 salgın sürecini ÖG’li çocuklarıyla evlerinde geçiren ebeveynlerin görüşlerinden alıntılara yer verilerek bulgular detaylı olarak rapor edilmiş, katılımcılar ve büyükşehir belediyesi yetkilileri ile paylaşılmıştır (Yıldııım ve Şimşek, 2018).

\section{Bulgular}

Kovid-19 salgınının yayılmasını önlemek amacıyla okulların kapatıldığı 16 Mart 2020 tarihinden itibaren günlerini ÖG’li çocuklarıla evlerinde geçiren ebeveynlerin görüşleri çevrim içi görüşme sorularına verdikleri yanıtlar ile betimlenmiştir. Böylece araştırmanın bulgularını oluşturan ebeveyn görüşleri dört tema ve alt temaları ile açıklanmıştır. Ebeveynlerin görüşlerini oluşturan dört tema; (1) Ebeveynlerin ÖERM tarafindan sunulan hizmetler hakkındaki görüşleri, (2) Ebeveynlerin ihtiyaç duydukları meslek elemanları, (3) Ebeveynlerin özel gereksinimli çocukları, kendileri ve aileleri ile ilgili ihtiyaçları, (4) Ebeveynlerin ihtiyaçlarının karşılanması yönündeki görüş ve önerilerdir. İzleyen bölümde her bir tema altında yer alan alt temalara ilişkin görüş bildiren anne ve babaların dağılımlarına yer verilmiş ve alt temalar doğrudan alıntılarla açıklanmıştır.

\section{Tema 1. Ebeveynlerin ÖERM Tarafindan Sunulan Hizmetler Hak- kındaki Görüşleri}

Ebeveynlerin ÖERM tarafindan 30 Mart 2020 tarihinden itibaren sunulan hizmetler ve sosyal medya aracılığıyla erişim sağladıkları paylaşımlar hakkındaki görüşleri Tablo 3 'te yer alan dört alt tema ile betimlenmiştir.

Tablo 3. Ebeveynlerin ÖERM Tarafından Sunulan Hizmetler Hakkındaki Görüşleri

\begin{tabular}{|c|c|c|}
\hline \multirow[t]{2}{*}{ Alt Temalar } & Anne $n=208$ & Baba $n=65$ \\
\hline & f & $\begin{array}{l}\mathbf{f} \\
\end{array}$ \\
\hline \multirow[t]{2}{*}{ Hizmetlerin yararlı olduğunu düşünenler } & Evet (Hayır) & Evet (Hayır) \\
\hline & $121(87)$ & $42(23)$ \\
\hline Hizmetlerin sunuluş türü (telefon, mesajlaşma, EBA) & 204 & 64 \\
\hline Yararlandıkları hizmetler & 147 & 24 \\
\hline $\begin{array}{l}\text { Sunulan hizmetler telefon, mesajlaşma, EBA dışında ya- } \\
\text { rarlanılan çevrim içi kaynaklar }\end{array}$ & 133 & 38 \\
\hline
\end{tabular}




\section{Hizmetlerin Yararlı Olduğunu Düşünenler}

ÖERM tarafından öğretmenler aracılığıyla öğrencilerin ihtiyaçları doğrultusunda hazırlanan etkinlik ve ödevleri ebeveynler ile telefon veya internet bağlantılı mesajlaşma uygulamalarıyla paylaşılmıştır. Ebeveynlerin çoğunluğu, evde uzaktan destekle etkinlik ve ödevleri yaptırmalarını ve sosyal medya paylaşımlarını yararlı olarak nitelendirmişlerdir. Olumsuz görüş bildiren anne ve babaların çocuklarının dikkatini toplama, sürdürme, odaklanma sorunu, bireysel uyaranlara ve ipuçlarına ihtiyaç duymaları nedeniyle hizmetlerden yararlanamadıkları görülmüştür. Annelerin 121'i hizmetlerin ihtiyaçlarını karşıladığını, 87 anne karşılamadığını; babaların ise 42'si ihtiyaçlarını karşıladığını, 23 baba ise karşılamadığını belirtmiştir. Olumlu görüş bildiren bir anne ve bir babanın görüşleri şöyledir: A46: "Görüntülü uzaktan eğitim çok faydalı oluyor. Bu eğitimlerin salgın sürecinden sonra seans günlerimizin dışında da devam etmesini isteriz." diyerek sürecin yararlı olduğunu vurgulamıştır. B63: "Evde kalıp uzaktan eğitime devam etmek istiyoruz." diyerek salgın gibi zorunlu hallerde çocuğunun eğitiminin kesintiye uğramamasından memnun olduğunu ifade etmiştir. Hizmetlerin yeterli olmadığını düşünen bir anne A70: "Telefonla canlı bağlantı çocuğuma verilen eğitimde hocama teşekkür ederim ama çocuğuma yeterli gelmiyor." diyerek uzaktan eğitimin çocuğunun eğitime erişimini sağlamadığını açıklamıştır.

\section{Hizmetlerin Sunuluş Türü}

Ebeveynler kendilerine ulaşan hizmetlerin genellikle öğretmenler tarafindan telefon ve mesajlaşma uygulamalarıyla ulaştığını ifade etmişlerdir. Ebeveynlerden 157 anne ve 45 baba öğretmenlerin en az haftada bir kez etkinlik önerileri ve ödev vermek için telefon ve mesajlaşma uygulamaları aracığıyla kendileriyle iletişim kurduklarını belirtmişlerdir. Ebeveynlerin merkez tarafından düzenlenen veya bireysel ulaştıkları sosyal medya platformları (Zoom, Google Meet ve Skype) aracıllğıyla sunulan uzman bilgilendirmelerine katıldıkları ve bu eğitimleri yararlı buldukları ancak uygulamalı eğitimlere ihtiyaç duyduklarını belirtmişlerdir. EBA'yı yalnızca altı anne ve bir babanın yararlı bulduğu görülmüştür. Bu konuda görüş bildiren bir baba B53: "EBA'yl açamadık. EBA'daki eğitimler yeterli değil." diyerek hem EBA'ya erişim sağlayamadığını hem de yararlanamadığını açıklamıştır. A31 ise: "EBA ve ögrencilerimizin eğitiminden verim alamadık. Oğlumun tedavileri uzaktan yapılıyor ondan da verim alamadık. Video atıyorlar yaptıramıyoruz." diyerek EBA'nın ve öğretmenin mesajlaşma uygulamasından yararlanamadığını ifade 
etmiştir. Dört anne ve bir baba ise merkez öğretmenlerinin kendileriyle iletişime geçmediğini bildirmişlerdir.

\section{Yararlandıkları Hizmetler}

Ebeveynlerin çoğunluğu kendilerine ulaştırılan hizmetlerden en çok yararlandıkları konunun çocuklarının eğitimiyle ilgili sorularının yanıtlanması olduğunu bildirmişlerdir. Bazı anneler ise çocuklarıyla evde yapabilecekleri etkinlik örnekleri verilmesinin çok yararlı olduğunu bildirmişlerdir. Ebeveynler üçüncü sırada spor, oyun, sanat ve fizyoterapi etkinlikleri için gönderilen videoların yararlı olduğunu ifade etmiştir. A244: "Çocuğumuza gönderilen etkinlikleri aile olarak evde çocuğumuzun eğitiminde çalışıyoruz." derken B54 ise: "Atölye ögretmeni bize çamur seramiği ile ilgili örnekler atıyor bu da bizim için iyi oluyor." demiştir.

\section{Sunulan Hizmetler Dışında Yararlanılan Çevrim İçi Kaynaklar}

Anne ve babaların çoğunluğu merkez tarafindan sunulan hizmetler d1şında sosyal medya platformları aracılığıyla (Zoom, Google Meet ve Skype) veya diğer ebeveyn gruplardan haberdar oldukları eğitimleri takip ettiklerini belirtmişlerdir. Özel eğitim alanı ile ilgili çevrim içi eğitimlere çok sık rastladıklarını dile getirmişlerdir. Genellikle bir alan uzmanı (öğretmen, öğretim üyesi) tarafından verilen bilgi aktarımına dayalı eğitimlerden memnun olmalarına rağmen uygulamalı ve görüntülü paylaşımların daha yararlı olacağını ifade ettikleri görülmüştür. Bu konuda görüş bildiren annelerden A126: "Sosyal medyada verilen dersleri takip ettim, yararl fakat uygulamal olarak verilmesini istiyorum." demiştir. A244: "Bir video kanall vb. site ile şifreli tüm eğitsel video kitap vb bir arada kütüphane niteliğinde olanlart izledik." demiştir. B40: "TV ile süreci takip ettik." demiştir. A157: "Instagram'dan hocalarınızı takip ediyoruz ilginiz için teşsekkürler, çok yararlıydı." diyerek sosyal medyanın bu süreçteki önemi vurgulamıştır.

\section{Tema 2. Ebeveynlerin İhtiyaç Duydukları Meslek Elemanları}

Özel eğitim kurumları, sağlık, eğitim ve sosyal hizmetler alanında sunulan destekler ÖG'li çocukların bakımı ve eğitiminde anne-babalara yardımcı olan hizmetlerdir. Kovid-19 salgını ÖG'li çocukların bu hizmetlere erişimlerini aniden sonlandırmıştır.

Karantina günlerinde ebeveynlerin en çok ihtiyaç duyduklan meslek elemanının özel eğitim öğretmenleri olduğu görülmüştür. Annelerden A200: "Ö̈̆retmenlerimiz özel eğitim ögrretmenleri tabii ki." diyerek yanıtlamıştır. 
İkinci sırada ihtiyaç duyulan personelin fizyoterapistler olduğu tespit edilmiştir. Ebeveynlerin üçüncü sırada ihtiyaç duydukları personelin ev içi spor etkinlikleri konusunda çocuklarına öneriler verebilecek beden eğitimi ve spor öğretmenleri olduğu, dördüncü ve beşinci sırada sırasıyla çocuk psikiyatristi ve etkinlik örnekleri sunabilecek meslek dersi öğretmenlerine ihtiyaç duydukları görülmüştür.

Tablo 4. Ebeveynlerin İhtiyaç Duydukları Meslek Elemanları

\begin{tabular}{lll}
\hline Meslek Elemanı & $\begin{array}{l}\text { Anne } \\
\mathbf{n = 2 0 8}\end{array}$ & $\begin{array}{l}\text { Baba } \\
\mathbf{n = 6 5}\end{array}$ \\
\hline & $\mathbf{f}$ & $\mathbf{f}$ \\
\cline { 2 - 3 } Özel eğitim öğretmeni & 81 & 24 \\
Fizyoterapist & 56 & 14 \\
Beden eğitimi ve spor öğretmenliği & 16 & 5 \\
Çocuk psikiyatristi & 10 & 3 \\
Meslek dersi öğretmeni & 10 & 3 \\
Diğer (berber, bakıcı, temizlikçi) & 10 & - \\
İhtiyacı yok & 7 & 6 \\
\hline
\end{tabular}

Bir grup annenin evde çocuklarının bakımı ve eğitimini üstlenecek bakıcı, yardımcı öğretmen ve berbere ve ev temizliğinde kendilerine yardımcı olabilecek kişilere ihtiyaç duydukları anlaşılmaktadır. Babalardan B49: "Çocuğum için ihtiyaç duyduğum en önemli şey fizik tedavi. Bir an önce kurumumuza ve fizyoterapistimize kavuşmak istiyoruz." diyerek fizyoterapistlere olan ihtiyacını dile getirmiştir.

\section{Tema 3. Ebeveynlerin Özel Gereksinimli Çocukları, Kendileri ve Aileleri ile İlgili İhtiyaçları}

Salgın, ÖG'li çocukların sağlık, eğitim ve terapi hizmetlerine erişimlerini kesintiye uğratmıştır. Dolayısıyla ebeveynleri destekleyen hizmetler de sonlanmıştır. Bu durumda ebeveynlerin öncelikli ihtiyaçlarının çocuklarının ihtiyaçları olduğunu tahmin etmek güç değildir. Ancak, sadece 23 annenin Çocuk Bakım Desteğini kendi ihtiyaçları olarak algıladıkları görülmüştür. Bu çalışmada görüş bildiren ebeveynlerin kendileri, aileleri ve ÖG'li çocuklarıyla ilgili ihtiyaçlarının örtüştügü görülmüştür. Ebeveynlerin kendileri ve aileleriyle ilgili ihtiyaçları (E) harfiyle ÖG'li çocuklarıyla ilgili ihtiyaçları (Ç) harfiyle gösterilmiştir. Tablo 5 'te ebeveynlerin ihtiyaçları annelerin en yoğun ihtiyaçları dikkate alınarak sıralanmıştır. Ebeveynlerin en yoğun ihtiyaçlarının eğitim konusunda olduğu görülmüştür. Eğitimin ardından diğer ihtiyaçların sırasıyla sosyal ve psikolojik destek, çocuk bakım desteği, ekonomik 
gereksinimler, sağlık ve terapi hizmetleri olduğu görülmüştür. Çocuk bakımı desteğini sadece annelerin ihtiyaç olarak bildirmesi dikkat çekicidir. Babaların en yoğun ihtiyaçlarının ise ekonomik gereksinimler yönünde olduğu görülmüştür. Az sayıda ebeveyn ihtiyaçları olmadığını bildirmişlerdir.

Tablo 5. Ebeveynlerin ÖG’li Çocukları, Kendileri ve Aileleri ile İlgili İhtiyaçları

\begin{tabular}{lll}
\hline Alt Temalar & $\begin{array}{l}\text { Anne } \\
\mathbf{n = 2 0 8}\end{array}$ & $\begin{array}{l}\text { Baba } \\
\mathbf{n = 6 5}\end{array}$ \\
\hline & $\mathbf{f}$ & $\mathbf{f}$ \\
\cline { 2 - 3 } Ĕgitim ihtiyacı (E-Ç) & 66 & 19 \\
Sosyal ve psikolojik destek (E-Ç) & 53 & 8 \\
Ekonomik gereksinimler (E-Ç) & 22 & 29 \\
Sağlık ve terapi hizmetleri (E-Ç) & 19 & 2 \\
İhtiyaç bildirmeme & 25 & 7 \\
\hline
\end{tabular}

\section{Ĕ̆itim İhtiyacı}

Ebeveynler, ne zaman sona ereceği belli olmayan salgın günlerinde çocuklarının eğitimden geri kalmaması için bu sorumluluğu üstlenerek kendileri eğitime ihtiyaç duyduklarını bildirmişlerdir. Ebeveynler eğitim ihtiyaçlarını çoğunlukla çocuklarının bireysel gelişimi, öğrenme özellikleri ve davranışlarını nasıl kontrol edecekleri hakkında bilgi edinmek ve evde çocuklarıyla yapabilecekleri oyun ve etkinlikler hakkında öneriler almak olarak açıklamışlardır. Anne ve babaların eğitim ihtiyaçlarını örnekleyen alıntılar şöyledir: A45: "Biz nasıl ögreteceğimizi bilmiyoruz. Okulda yapılanları sadece tekrar ediyoruz.". Bir anne (A159) evde çocuğuyla nitelikli oyun zamanı oluşturmak için; "Özel çocuğum için sadece eğitiminin aksamaması ve oyunu nasıl oynayacağımı öğrenmem gerekiyor." demiştir. Zihin yetersizliğine sahip oğlu olan bir baba B48: "Bizim sadece çocuğumuzun gelişimi için ihtiyaç duyduğumuz tek şey eğitimi. Bu süreçte ne tür etkinlikler yapacağımızı ve nasıl yapacağımızı bilmek istiyoruz." diyerek öncelikli ihtiyacının çocuğunun eğitimi olduğunu vurgulamıştır. OSB oğlu olan bir baba B58: "Çocuğumuz için düzenli bir biçimde ve daha çok eğitim ve etkinlik desteklerine ihtiyaç duyabiliyoruz." diyerek etkinlik önerilerine kısa süreli değil daha sistemli bir biçimde uzun süreli ihtiyaç duyduklarını belirtmiştir.

Görüş bildiren ebeveynlerin çoğunluğu çocuklarının eğitimi için kendilerinin eğitime ihtiyaçları olduğunu dile getirseler de bazı ebeveynler kendilerinin çocukları tarafından eğitimci olarak dikkate alınmadığını ifade etmişlerdir. Bazı ebeveynler, uzaktan eğitimin çocukları için uygun olmadığını, 
çevrim içi olacaksa bile çocukları için çevrim içi bireysel eğitim veya evde bire bir eğitimlere ihtiyaç duyduklarını belirtmişlerdir. Örneğin bir anne A70: "Eğitimlerin evde olması gerekiyor, uzaktan çok zor..." diyerek yüz yüze eğitimin gerekliliğini vurgulamıştır. Bir başka anne A78: "Online derslerin çocuğumun ihtiyacına göre yani bireysel olması gerekiyor." demiştir.

\section{Sosyal ve Psikolojik Destekler}

Ebeveynler çoğunlukla, sokağa çıkma yasakları, sosyal mesafe ve temizlik tedbirleri nedeniyle arkadaş ve akrabaları ile etkileşimlerinin sınırlandığını, yürüyüş, çay saatleri vb. etkinliklere katılamadıklarını, tedavi ve kişisel bakımlarını ertelediklerini dile getirmişlerdir. Ebeveynler kendilerini güçlendiren, cesaret ve keyif veren sosyal desteklerini kaybetmenin duygu durumlarını ve psikolojilerini bozduğunu hem kendileri hem de çocukları için karantina günlerinin zorlu geçtiğini ve psikolojik desteğe ihtiyaç duyduklarını belirtmişlerdir. Ebeveynlerin görüşlerini örnekleyen alıntılar şöyledir: B64: "Bu süreçte ilk önce psikolojik destek. Çünkü bu süreç çok uzun ve çok sikıldık artık.", A191: "Hiçbir fikrim yok bocalamadayım, kendime tahammülüm yok.", A59: "Artık kendime vakit ayırmak istiyorum. Tek başıma kahve içmek istiyorum."

Ebeveynler karantina nedeniyle öğretmenlerinden, akranlarından ve okul ortamından uzak kalan çocuklarının evde uzun süre kalmalarının da sosyal ve duygusal gelişimlerinde olumsuz etkileri olduğuna işaret etmişlerdir. Bu görüşleri açıklayan alıntılar şöyledir: A31: “Özel çocuğumuzun eğitimi için doğal ortam çok fazla gerekli evde çok zor oluyor çocuğumun da tanısı ağır otizm çok zor." diyerek açık alan ihtiyacını vurgulamıştır. B43: "Çocuğun sosyalleşmesine yönelik iletişim becerilerinin kazandırlmasiyla ilgili desteğe ihtiyaç duyuyoruz." diyerek akran etkileşimlerinin kısıtlanmasının zorluğuna işaret etmiştir.

\section{Ekonomik Gereksinimler}

Ebeveynlerin bu alt tema altında ÖG'li çocuklarının ihtiyaçlarını sıraladıkları, kendilerine yönelik ihtiyaçlarının da yine çocuklarının ihtiyaçlarını karş1lamaya yönelik olduğu görülmüştür. Ekonomik gereksinimler alt temasında daha çok babaların; gıda yardımı, iş desteği ve çocukları için tıbbi araçgereç desteği hakkında görüş bildirdiği görülmüştür. Anneler ise çocukları için eğitici araç ve gereç desteği, eğitim ücreti desteği, bakım ürünlerinin masrafi, internet aboneliği, spor malzemesi, tablet, bilgisayar vb. gibi elektronik ürünler için ekonomik desteğe ihtiyaç duyduklarını belirtmişlerdir. Anne ve 
babaların görüşlerine ilişkin alıntılar şöyledir: B43: "Maddi desteğe ihtiyaç duyuyorum. Tek çalışan ben olduğum için zor.", A16: "Maddi olarak interneti karşılamıyoruz ve eğitimden geri kalıyoruz.", A143: "Evde çok slkıldılar, eşim tek çalışıyor, çocuklara evde yapabilecekleri spor malzemeleri dağıtmaları çok iyi olurdu."

\section{Sağlık ve Terapi Hizmetleri}

Ebeveynler, sağlik ve terapi hizmetleri alt temasında çoğunlukla çocuklarının tedavi ve terapi hizmetlerine devam edemediklerini vurgulamışlardır. Bazı ebeveynler uzun süre evde hareketsiz kaldıklarını, beslenme alışkanlıkları ve rutinleri değiştiği için kilo aldıklarını dolayısıyla egzersiz yapmaya ve diyetisyen desteğine ihtiyaç duyduklarını belirtmişlerdir. Eşleri çalışan az sayıda ebeveyn, çocuklarını rutin kontrolleri için hastaneye götürmede yardıma ihtiyaç duyduklarını dile getirmiştir. Anne ve babaların ihtiyaçlarını örnekleyen alıntılar şöyledir: B30: "Evde sıkıldık, dışarı çıkıp gezmek istiyoruz." ve A129: “Artık oturmaktan, yemekten kilo aldık. Nasıl gidecek bunlar?" diyerek fiziksel aktivite ve diyetisyene ihtiyaç duyduğunu açıklamıştır. A189: "Eşim çallşlyor, ben tekim ve çocuğumu hastaneye götürüp getirmek çok zordu benim için. Bir çözüm olmall." Anneler, çocukları için dil ve konuşma terapisi, fizyoterapi, diyetisyen desteği, kullandıkları düzenli ilaçların temini ve fiziksel aktivite desteğine, babalar ise salgın kapsamında önerilen hijyen malzemeleri ve çocuklarının yetersizlik türüne uygun cihazlara (işitme cihazı pili, tekerlekli sandalye vb.) ihtiyaç duyduklarını belirtmişlerdir. B63: "Maske ve temizlik ürünleri ek masraf oldu ve bu süreç maddi olarak zorlaştl, desteğe ihtiyacımız var." diyerek salgına yönelik yeni tedbirler gereği ihtiyaçlarının çeşitlendiğini ifade etmiştir.

\section{İhtiyaç Bildirmeme}

Ebeveynler arasında bir grup anne ve baba salgın sürecinde ihtiyaçlarının olmadığını, gerektiğinde ihtiyaçlarını kendilerinin karşılayabildiğini ifade etmişlerdir. A135: "Hiçbir şeye ihtiyaç duymuyorum kendim hallediyorum." ve B57: "Çok şükür ihtiyaç hissedecek bir sıkıntımız yok." diyerek ihtiyaçlar1nın olmadığını belirtmişlerdir.

\section{Tema 4. Ebeveynlerin İhtiyaçlarının Karşılanması Yönündeki Önerileri}

Ebeveynler karantina günlerinde hem kendileri hem de ÖG'li çocuklarının ihtiyaçlarının karşılanmasına yönelik önerilerinin eğitim hizmetleri, sosyal ve psikolojik destek, sağlık ve terapi hizmetleri alt boyutunda örtüştüğü 
görülmüştür. Ebeveynlerin salgının sona ermesi ile ilgili iyi dileklerini kendileri için ihtiyaç olarak vurguladıkları görülmüştür. $\mathrm{Bu}$ durum çocukların sorumluluğunun tamamen annelerde olmasından kaynaklandığ 1 düşünülmektedir. Benzer biçimde okula gitmenin çocukların görevleri gibi algılandığı anlaşılmaktadır. Ebeveynlerin kendileri ve aileleriyle ilgili önerileri (E) harfiyle ÖG'li çocuklarıyla ilgili önerileri (Ç) harfiyle Tablo 6'da gösterilmiştir.

Tablo 6. Ebeveynlerin İhtiyaçlarının Karşılanması Yönündeki Önerileri

\begin{tabular}{lll}
\hline Alt Temalar & $\begin{array}{l}\text { Anne } \\
\mathbf{n = 2 0 8}\end{array}$ & $\begin{array}{l}\text { Baba } \\
\mathbf{n = 6 5}\end{array}$ \\
\hline & $\mathbf{f}$ & $\mathbf{f}$ \\
\cline { 2 - 3 } Ĕ̈itim hizmetleri ile ilgili öneriler (E-Ç) & 56 & 20 \\
Sosyal ve psikolojik destek ile ilgili öneriler (E-Ç) & 37 & 5 \\
Sağlık ve terapi hizmetleri ile ilgili öneriler (E-Ç) & 14 & 4 \\
Öneri bildirmeme & 48 & 12 \\
\hline
\end{tabular}

\section{Eğitim Hizmetleri ile İlgili Öneriler}

Ebeveynlerin çocuklarının eğitimiyle ilgili önerileri; çevrim içi ders sayısı ve süresinin artırılması, öğretmen ve akranları ile sanal medya üzerinden etkileşim saatlerinin düzenlenmesi, EBA'ya erişim kolaylı̆̆ sağlanması, ÖG'li öğrenciler için EBA'nın yeniden düzenlenmesi ve evde özel bireysel eğitim verilmesi şeklindedir. Anne ve babaların çocuklarının eğitimine yönelik önerilerine rağmen yüz yüze eğitimin bir an önce başlamasını diledikleri görülmüştür. Anne ve babaların önerilerine ilişkin alıntılar şöyledir: A4: "Zorlu süreçte eğitime ara verilmesi otizmli çocukları çok etkiledi ve bunun için sosyal mesafeli ve kurall en azından haftada bir gün eğitim almalılar." ve A21: "Bu çocuklar daha evlere kapanmaya ne kadar dayanabilecekler bilmiyorum. Bizim için çok stresli bir dönem. Onları en az haftada bir kaç gün sosyalleştirmek adına küçük küçük eğitimler başlamalı ya da çevrim içi bireysel eğitim olmall." diyerek hem yüz yüze eğitimi hem de çevrim içi eğitimlerin bireyselleştirilmesini önermişlerdir. B46 ise MEB'in sunmuş olduğu hizmetlere yönelik: "EBA'yı açamadık. EBA'daki özel eğitim ile ilgili eğitimler çocuğumuza uygun değil. Materyalimiz yok." diyerek EBA'ya erişimde sorun yaşadıklarını ve EBA'da özel eğitim etkinliklerinin her bir öğrencinin ihtiyacını karşılayamadığını belirtmişlerdir. Ebeveynler kendileri için aile eğitimlerinin sürmesini ve çocuklarının bireysel farklılıklarından dolayı daha çok uygulamalı eğitimler düzenlenmesini önermişlerdir. 


\section{Sosyal ve Psikolojik Destek ile İlgili Öneriler}

Ebeveynler okulların kapatılması, işten çıkarılma, maddi zorluklar ve evde artan görevleri gibi nedenlerle psikolojik olarak yıprandıklarını ifade etmişlerdir. Anne ve babalar bu bağlamda kendilerine yönelik önerileri; ebeveyn gruplarıyla iletişim kurabilme, uzmanlarla iletişim kurabilme ve gerektiğinde mesajlaşma uygulamalarıyla sosyal ve psikolojik danışma hizmeti alabilme olarak sıralamışlardır. Bir annenin önerisi şöyledir: A49: "Bu süreçte ev hanımlarının iş yükümlülüğü daha çok arttı, sorumluluklarımız fazlalaştı. Hani ne kadar da olsa bizim de psikolojik desteğe ihtiyacımız var." Ebeveynlerin çocukları adına önerileri arasında; açı alanlar, yürüyüş yolları ve spor merkezlerinin açık olması şeklindedir. Ayrıca ebeveynler çocukları için sosyal medya uygulamalarıyla öğretmenleri ve akranlarıyla bir araya gelecekleri rutinlerin oluşturulmasını, sürprizlerin yapılmasını, doğum günü ve oyun etkinlikleri düzenlenmesini önermişlerdir. Annelerden A66'nın önerisi: “Eğitiminden memnunuz. Çocuklarımız arada nefes almak için çıkabilseler, spor yapsalar. Kolaylık sağlansa...” şeklindedir.

\section{Sağlık ve Terapi Hizmetleri ile İlgili Öneriler}

Bazı ebeveynlerin, salgın sürecinde risk grubunda olan çocukları için çoğunlukla dile getirdikleri önerileri; sağlık hizmetlerine ulaşmada kolaylık, tedavi ve terapileriyle ilgili ilaç ve malzemelerin eve teslim edilmesi yönündedir. Ayrıca bu süreçte çocuklarını dışarıya çıkarmak istemeyen bazı ebeveynler hem kendileri hem de çocuklarının sağlık kontrollerinin evde yapılmasını önermişlerdir. Bu görüşleri örnekleyen alıntılar: A75: "Düzenli kontrollerimize gidemiyoruz. Sağllk personellerin eve gelip ilaç yazmalarını istiyoruz. Eczaneden borç alıp yazamıyoruz. Bu bizim için sorun." diyerek ilaç temini ile ilgili sıkıntılarını dile getirmiştir. B39: "Salgın nedeniyle devam edemeyen çocuğum için materyal ve egzersiz aletlerinin temini..." diyerek terapi için gerekli araç-gereçlerin eve verilmesini önermiştir.

\section{Öneri Bildirmeme}

Az sayıda ebeveyn öneride bulunmak istemediklerini ifade etmişlerdir. Bir anne önerilerinin çok dikkate alınmadığını düşündüğü için öneride bulunmadığını belirtmiştir. A12: "Hep talep ettik, hiçbir şeyimiz olmadı. O yüzden önerim yok." diyerek sitemini bildirmiştir.

\section{Tartışma}

Kovid-19 salgınının yayılmasını önlemek için okulların kapatılması ve yüz yüze eğitime ara verilmesi, birçok ülkede alınan ilk tedbirler arasında yer almıştır. Böylece ÖG'li çocuklara sunulan birçok hizmet gibi eğitim 
hizmetlerine de ara verilmiş ve çocuklar evlerinde ebeveynleriyle baş başa kalmışlardır. Bu çalışma Gaziantep ilinde karantina günlerini evlerinde 2-20 yaş arasındaki ÖG'li çocuklarıla birlikte geçiren ebeveynlerin ihtiyaçlarını ve sunulan hizmetler hakkındaki görüşlerini belirlemeyi amaçlamıştır. Çalışmanın katılımcıları, çocukları için bir ÖERM'den destek eğitim hizmeti alan 273 ebeveyndir. Merkez yönetimi ebeveynleri desteklemeye yönelik iki tür uzaktan eğitim uygulamasını 30 Mart 2020 tarihinde uygulamaya başlamıştır. İlki, merkezde görevli özel eğitim öğretmenleri tarafından öğrencilerin bireysel ihtiyaçları doğrultusunda hazırlanan ödev ve etkinlikleri, ailelerin evde uygulayabilmesi için telefon görüşmeleri ve mesajlaşma uygulamalarıyla paylaşımlarına dayalıdır. Diğeri ise sanal medya aracılığıyla ebeveynlere özel eğitim alanında sunulan eğitim içerikli paylaşımlardır. Veriler, 28/04/202020/05/2020 tarihleri arasında ebeveynlerin açık uçlu dört soruya çevrim içi ortamda verdikleri yanıtlardan elde edilmiştir. Çalışmanın bulguları dört tema altında betimlenmiştir: (1) Ebeveynlerin ÖERM tarafından sunulan hizmetler hakkındaki görüşleri, (2) Ebeveynlerin ihtiyaç duydukları meslek elemanları, (3) Ebeveynlerin ÖG'li çocukları, kendileri ve aileleri ile ilgili ihtiyaçları, (4) Ebeveynlerin ihtiyaçlarının karşılanması yönündeki önerileridir. İzleyen bölümde her bir tema, alan yazın doğrultusunda tartışılmıştır.

\section{Ebeveynlerin ÖERM Tarafından Sunulan Hizmetler Hakkındaki Görüşleri}

Ebeveynlerin çoğunun, ÖERM öğretmenleri tarafından kısa sürede hayata geçirilen ödev ve etkinlik uygulamalarını, çocuklarının eğitimi kesintiye uğramadığ 1 ve öğretmenlerle iletişimleri kopmadığ için yararlı buldukları görülmüştür. Daha az sayıda ebeveyn; çocuklarının dikkatini toplama ve sürdürme, odaklanma sorunu, bireysel uyaranlara ve ipuçlarına ihtiyaç duymaları nedeniyle uzaktan sunulan hizmetlerden yararlanamadıklarını belirtmiştir. Ebeveynlerin çocuklarının dokuz ayrı yetersizlik türüne sahip oluşu ve bireysel gereksinimlerinin farklılığı nedeniyle merkezin sunduğu hizmetten tüm çocukların yararlanmasını beklemek gerçekçi olmayacaktır. Kovid 19 salgını ilanının ilk günlerinde İngiltere'de ÖG'li çocukların ebeveynleriyle yapılan bir çalışmada da okul personeli tarafından sunulan hizmetlerden ebeveynlerin üçte ikisinin memnun olduğu, diğerlerinin ise çocuklarının bireysel ihtiyaçları sağlık ve terapi ağırlıklı olduğu için ihtiyaçlarını karşılamadığı ve yararlı bulmadığı görülmüsstür (Toseeb ve ark., 2020). Uzaktan eğitim uygulamalarının ÖG'li çocukların yetersizlik türleri ve düzeylerinin farklı olması nedeniyle değişen ve çeşitlenen ihtiyaçlarını eşit derecede karşılaması mümkün 
görünmemektedir (Kayhan ve Özaydın, 2017). Erken dönemde gelişimsel yetersizlikleri, gerilikleri olan ve gelişimleri risk altında olan çocukların ve ailelerinin de ihtiyaçlarının çok değişken olduğu bilinmektedir. Bu durumda Guralnick (2011), erken müdahale programları hazırlamanın en zor yanını, çocukların farklı yetersizliklerinden ve ebeveynlerin farklı ihtiyaçlarından dolayı geniş bir ihtiyaçlar yelpazesine sahip oluşları olarak açıklamıştır.

$\mathrm{Bu}$ çalışmada merkez yönetim tarafindan başlatılan uygulamayla öğretmenlerin kısa sürede ebeveynlerle iletişime geçip çevrim içi eğitimleri gayretle sürdürdükleri görülmüştür. Ancak okulların kapatılmasını takip eden günlerde bazı özel eğitim öğretmeninin öğrencilerinin okul ortamından uzak kalmamaları adına telefon veya mesaj yoluyla ebeveynleri aracılığıyla öğrencilerine günlük ödevler vererek eğitimde sürekliliği sağladıkları görülmüştür (Çakın ve Akyavuz, 2020; Karahan ve ark., 2020). Kovid 19 salgını bu fedakâr öğretmenlerin mesleklerini sürdürmelerini engelleyememiştir.

Kovid-19 salgınının uzaktan çevrim içi sistemlerin kullanımını yaygınlaştırdığı görülmüştür (Cluver ve ark., 2020; Narzisi, 2020; UNICEF, 2020; WHO, 2020; Yarımkaya ve Esentürk, 2020). EBA uzaktan eğitim sistemi tipik gelişen öğrenciler için hızlıca hayata geçirilen nitelikli bir uygulama olsa da, bu çalışmada ÖG'li öğrencilerin ebeveynleri EBA'dan yararlanamadıklarını dile getirmişlerdir. Bu durum TV üzerinden gerçekleştirilen eğitim uygulamalarının tek yönlü bilgi aktarımına dayalı oluşu nedeniyle ÖG'li öğrencilerin ihtiyaçlarını karşılamadığını düşündürmektedir. EBA'da bulunan içerik ve uygulamaların nicelik ve niteliğinin ÖG'li öğrenciler için yeterli olmadığını bildiren araştırma bulguları da vardır (Can, 2020; Yılmaz ve ark., 2020). Ayrıca teknoloji araçlarına düşkün olan ÖG'li bazı öğrencilerin TV üzerinden EBA'y1 ebeveyn kontrolünde izlemelerini de gerektirmektedir (Can, 2020; Karahan ve ark., 2020). Ülkemiz "sosyal medya"yla tanışalı çok uzun zaman olmasa da çalışmaya katılan ebeveynlerin karantina günlerinde dijital yetkinliklerinin oluştuğu ve sosyal medya (Instagram-youtube-twitter) uygulamalarını sıklıkla takip ettikleri görülmüştür.

\section{Ebeveynlerin İhtiyaç Duydukları Meslek Elemanları}

Ebeveynler salgın sürecinde ÖG'li çocuklarıyla ilgili bilgi almak için en çok özel eğitim öğretmenlerine ihtiyaç duymuşlardır. Ebeveynlerin özel eğitim öğretmenleri tarafından sunulan eğitimleri yararlı buldukları görülmüştür. Benzer araştırmalarda da ebeveynlerin, çocuklarının gereksinimleri doğrultusunda bireysel öneriler sundukları için özel eğitim uzmanı veya 
öğretmenlerine güvendikleri görülmüştür (Asbury ve ark., 2020; Toseeb ve ark., 2020). Bu çalışmada özel eğitim öğretmenlerinden sonra ebeveynlerin ihtiyaç duydukları personelin fizyoterapist, beden eğitimi ve spor öğretmeni hatta berber, bakıcı ve temizlik görevlisi olarak çeşitlendiği görülmüştür. Araştırmalar ÖG'li çocukların yetersizliklerine veya gelişim düzeylerine göre farklılaşan ihtiyaçları nedeniyle ebeveynlerin birçok meslek elemanına ihtiyaç duyabileceklerini göstermiştir (Bailey ve ark., 2006; Burton-Smith ve ark., 2009; Chen ve Simeonsson, 1994). Bu çalışmada ebeveynlerin fizyoterapist ve beden eğitimi öğretmenlerine ihtiyaç duymaları, katılımcılar arasında en çok bedensel yetersizliği olan çocuklara sahip ebeveynlerin oluşu ile açıklanabilir. Aslında tüm çocuklar, hatta ebeveynler uzun süre evde kaldıkları ve hareketsiz bir hayat sürdürdükleri için spor etkinliklerinin birçok araştırmada önerildiği görülmüştür (Cacioppo ve ark., 2021; Ercan ve ark.., 2020; Yarımkaya ve Esentürk, 2020). Dünya Sağlı Örgütü (2020), ÖG'li çocukların karantina günlerinde ruh sağlıklarını ve hayat kalitelerini destekleyecek fiziksel aktivitelere ve rahatlama tekniklerine ihtiyaç duyduklarını vurgulamıştır (Avrupa WHO [EWHO], 2020).

\section{Ebeveynlerin ÖG'li Çocukları, Kendileri ve Aileleri ile İlgili İhti- yaçları}

Ebeveynlerin çoğunluğu en yoğun ihtiyaçlarının çocuklarının eğitimi ve onların ihtiyaçlarını karşılama konusunda kendilerinin bilgi edinme ihtiyaçları olduğunu ifade etmişlerdir. Eğitim ihtiyaçlarının ardından sosyal ve psikolojik destek, çocuk bakım desteği, ekonomik destek, sağlık ve terapi desteklerine ihtiyaç duydukları görülmüştür. Araştırmalar, ÖG’li çocuklara sahip ebeveynlerin bilgi edinme ihtiyaçlarının küresel bir olgu olduğunu göstermektedir (Bailey ve ark., 2006; Chen ve Simeonsson, 1994).

$\mathrm{Bu}$ çalışmada daha çok annelerin sosyal ve psikolojik desteğe ihtiyaç duydukları görülmüştür. Türkiye'de ÖG'li çocukların birincil sorumluluğunun annelerde olduğu düşünüldüğünde bu bulgu şaşırtıcı bir sonuç değildir (TÜİK, 2010). Annelerin salgın döneminde artan sorumluluklarının aksine akraba ve arkadaş çevresinden uzak kalmaları ve kendilerine ayırdıkları özel zamanın azalması nedeniyle kaygılarının arttığı anlaşılmıştır. Salgının ilanını izleyen günlerde yapılan araştırmalarda ebeveynlerin ve ÖG'li çocuklarının ruh sağlıklarının olumsuz etkilendiği belirtilmiştir (Asbury ve ark.; 2020; Başaran ve Aksoy, 2020; Drogomyretska, Fox ve Colbert, 2020; Lee, 2020; Manning, Billian Matson, Allen ve Soares, 2020; Wigg ve ark., 2020). Salgın nedeniyle 
iş kaybı yaşayan ebeveynlerin ekonomik kaygılarının da ruh sağlıklarını olumsuz etkilediği görülmüştür (Cluver ve ark., 2020; Lee, 2020; Manning, Billian, Matson, Allen ve Soares, 2020). Wigg ve ark. (2020), ÖG'li çocukların okulların kapalı oluşu nedeniyle akranları ve öğretmenleriyle etkileşimlerinin sınırlanmasını kaygılarının kaynağı olarak belirtmişlerdir. OSB olan bireylerin Ebola ve SARS salgınında alınan sosyal izolasyon tedbirleri nedeniyle ruh sağlı̆ğ sorunları yaşadıkları hatta intihar nedeniyle ölüm olasılıklarının toplumun diğer bireylerine oranla dokuz kat daha fazla olduğu vurgulanmıştır (Den Houting, 2020; Jalloh ve ark., 2018). Bu durum ÖG'li çocukları olan ebeveynlere bakım hizmeti karşılığ verilen mali destek gibi çocukların ve annelerin psiko sosyal refahı adına sosyal ve psikolojik destekler bir an önce uygulamaya konulmalıdır.

Bu çalışmada salgın döneminde herhangi bir ihtiyaçları olmadığını belirten ebeveynlerin oluşu salgının tüm ailelerinin ruh sağlığı üzerinde olumsuz bir etki bırakmadığını göstermiştir. Hatta karantina günlerinin aile üyelerini bir araya getirerek olumlu etkileşimlere yol açtığını bildiren araştırma bulgularına da rastlanmıştır (Asbury ve ark., 2020; Cahapay, 2020; Majoko ve Dudu, 2020; Toseeb ve ark., 2020). Ailelerin sosyal ve ekonomik desteklere sahip oluşlarının yetersizliği olan çocuklara sahip olsalar da risklerle daha kolay baş edebildiklerini göstermiştir (Guralnick, 2011).

Çalışmanın ayırt edici bir bulgusu, annelerin çocuk bakım desteğine ihtiyaç duyduklarını dile getirmeleridir. Okul ve gündüz bakım merkezleri kapalı olduğu gibi aile yakınlarından veya komşularından destek alamayan ve çalışmak zorunda olan annelerin çocuklarının günlük ve saatlik bakımı konusunda yardımcı bir kişiye ihtiyaçları olduğu anlaşılmaktadır. Ayrıca, OSB olan çocukların ebeveynlerinin sağlık hizmetlerine ve evde bakım desteğine ihtiyaç duymalarının birçok araştırmanın bulguları arasında yer alışı evrensel bir ihtiyaç olduğunu göstermektedir (Burton-Smith ve ark., 2009; Colizzi ve ark., 2020; Özaydın, 2020b; Yıldırım ve Hacıfazlığlu, 2019).

Anneler ekonomik gereksinimlerinin çocuklarının eğitimi ile ilgili olduğunu belirtirken babalar gıda ve çocuklarının temel ihtiyaçları için olduğunu belirtmişlerdir. Bu durum, ülkemizde ÖG'li çocukların sorumluluğunun çoğunlukla annelerde olduğu, evin ve çocukların ihtiyaçlarını karşılamak için maddi kazanç sağlama görevinin de babalarda olduğunu gösteren araştırma bulgularıyla örtüşmektedir (Demirbilek, 2013; Gören, 2015; Turan-Gürhopur ve İşler-Dalgıç, 2017; TÜİK, 2010). 


\section{Ebeveynlerin İhtiyaçlarının Karşılanması Yönündeki Önerileri}

Ebeveynlerin ihtiyaçlarının karşılanmasına yönelik önerileri; eğitim, sosyal ve psikolojik destek, okullar, sağlık ve terapi hizmetleri ve iyi dilekler olarak gruplandırılmıştır. Ebeveynlerin eğitim süreci ile ilgili önerileri; çevrim içi ders sayısı ve süresinin artırılması, özel eğitim öğretmenleriyle yüz yüze eğitimin başlaması, EBA'ya erişim için ailelere internet desteği sağlanması ve EBA'nın içeriğinin ÖG'li çocuklar için daha erişilebilir ve kapsamlı düzenlenmesi olarak sıralanmıştır. Ebeveynlerin önerilerinin çoğunlukla çocuklarına yönelik hizmetlerin iyileştirilmesi yönünde olduğu görülmüştür. Diğer araştırma bulguları da ebeveynlerin salgının bir an önce sona ermesini ve çocuklarının yüz yüze eğitime tekrar başlamasını beklediklerini göstermektedir (Asbury ve ark., 2020; Toseeb ve ark., 2020). Ebeveynlerin, çocuklarının eğitimlerinde aktif rol almak için uygulamalı eğitimlere ihtiyaçları oldukları bilinmektedir (Yazıcı ve Durmuşoğlu, 2017). ÖG'li çocukların eğitim süreçlerinde ebeveynleri eğitici aktörler haline getirmek, çocukların hayatlarındaki risklerin azalmasını sağlarken öğrenme süreçlerini de destekleyecektir (Bailey ve ark., 2006; Guralnick, 2011).

Ebeveynlerin salgın sürecinde ortaya çıkan tele-sağlık hizmetlerinden kendilerinin ve çocuklarının ruh ve beden sağlığı için de faydalanmayı bekledikleri görülmüştür. Kovid-19 salgını çevrim içi kanalların eğitim alanında aktif kullanılmasını sağladığ da hızlandırmıştır (Di Carlo ve ark., 2020; Kerem-Günel, 2020). Bu çalışmada ebeveynler kendileri ve çocukları için açık alanlara ve spor merkezlerine ihtiyaç duyduklarını belirtmişlerdir. Özellikle OSB'li çocukların ebeveynleri tarafindan da bu tür merkezlere ve alanlara ihtiyaç duyulduğu görülmüş̧ür (Özaydın ve Uşak, 2014). Özetle, ÖG'li çocuklara sahip ebeveynler Kovid-19 ile birlikte alışılmadık bu yeni sürece adapte olmakta zorlanmıştır. Bunun yanı sıra ebeveynlerin gereksinimlerinin salgın öncesine göre çok değişmediği de görülmüştür.

\section{Sonuç}

Karantina günleri ebeveynlerin çocuklarının eğitimiyle ilgili sorumluluklarını artırmıştır. Hızla hayata geçirilen uzaktan eğitim uygulamaları birçok ÖG'li çocuğun tek başına izlemesi ve öğrenmesi için uygun firsatlar sunamamıştır. Ebeveynler, çocuklarını değişen rutinlere alıştırma, öğrenme ortamlarına dâhil etme ve çocuklarının gelişimleri konusunda bilgi edinme ihtiyacı duymuşlardır. Bu bilgileri öncelikle özel eğitim öğretmenlerinden almayı tercih etmişler ve öğretmenlerin çocuklarının bireysel ihtiyaçları doğrultusunda 
hazırladıkları ödev ve etkinlikleri kendileriyle paylaşmalarını ve haftada bir kez iletişim kurmalarını yararlı bulmuşlardır. Kovid-19 salgını çevrim içi sistemlerin kullanımı yaygınlaştırmış ve bu çalışmadaki ebeveynlerinde sıklıkla takip ettiği görülmüştür. Ancak EBA uzaktan eğitim sisteminin ÖG'li çocuklar için çok yararlı olmadığı anlaşılmaktadır. Çocuklarına evde öğretmen olmanın zorluğunu yaşayan ebeveynlere ileride olabilecek benzer karantina durumları için akademik, sosyal ve günlük hayat becerileri öğretimiyle ilgili el kitapçıkları, videolar ve eğitim materyalleri basılı ve elektronik kopya olarak hazırlanmalıdır. Ebeveynler çocukları için park, yürüyüş yolları ve spor merkezlerinin açık olmasını, sosyal medya uygulamalarıyla öğretmenleri ve akranlarıyla bir araya gelecekleri rutinlerin oluşturulmasını, sürprizlerin yapılmasını, doğum günü ve oyun etkinlikleri düzenlenmesini önermişlerdir. Ailelere, uzaktan eğitime devam edecek çocuklarının ihtiyaçları için bu süreçte üstlendikleri birçok rolü yönetebilmeleri için destek eğitim programları hazırlanmalıdır. Ayrıca olası karantina durumları için ebeveynlere ve çocuklara yönelik tele-sağlık uygulamalarıyla sosyal ve psikolojik desteklerin verilmesi yasal düzenlemelerle güvence altına alınmalıdır.

\section{Kaynakça}

Asbury, K., Fox, L., Deniz, E., Code, A. ve Toseeb, U. (2020). How is COVID-19 affecting the mental health of children with special educational needs and disabilities and their families? Journal of Autism and Developmental Disorders, $51,1-9$.

Doi: https://doi.org/10.1007/s10803-020-04577-2

Atl1-Y1lmaz, E. ve Atl1, A. (2020). Otizm spektrum bozukluğu olan bireylerde Covid19 pandemisinde uyulması gereken kuralların video modelle öğretilmesi. International Journal of Social Sciences and Education Research, 6(2), 282-293.

Bailey, D. B., Jr., Blasco, P. M. ve Simeonsson, R. J. (1992). Needs expressed by mothers and fathers of young children with disabilities. American Journal of Mental Retardation, 97(1), 1-10. https://www.researchgate.net/publication/21768452

Bailey, D. B., Bruder, M. B., Hebbeler, K., Carta, J., Defosset, M., Greenwood, C., Kahn, L., Mallik, S., Markowitz., J., Spiker, D., Walker, D. ve Barton, L. (2006). Recommended outcomes for families of young children with disabilities. Journal of Early Intervention, 28, 227-251.

Başaran, M. ve Aksoy, A. B. (2020). Anne-babaların korona-virüs (Covid-19) salgını sürecinde aile yaşantılarına ilişkin görüşleri. Uluslararası Sosyal Araştırmalar Dergisi, 13(7), 668-678.

Burton-Smith, R., McVilly, K. R., Yazbeck, M., Parmenter, T. R. ve Tsutsui, T. (2009). Service and support needs of Australian carers supporting a family member with disability at home. Journal of Intellectual \& Developmental Disability, 34, 239-247.

Doi: $10.1080 / 13668250903103668$ 
Cacioppo, M., Bouvier, S., Bailly, R., Houx, L., Lempereur, M., Mensah-Gourmel, J., Kandalaft, C., Varengue, R., Chatelin, A., Vagnoni, J., Vuillerot, C., Gautheron, V., Dinomais, M., Dheilly, E., Brochard, S., Pons, C. ve ECHO Group. (2020). Emerging health challenges for children with physical disabilities and their parents during the COVID-19 pandemic: The ECHO French survey. Annals of Physical and Rehabilitation Medicine, 64(3), 1-8.

Doi: 10.1016/j.rehab.2020.08.001

Cahapay, M. B. (2020). Rethinking education in the new normal post-COVID-19 era: A curriculum studies perspective. Aquademia, 4(2), 1-5.

Doi: 10.29333 /aquademia/8315

Can, E. (2020). Coronavirüs (Covid-19) pandemisi ve pedagojik yansımaları: Türkiye'de açık ve uzaktan eğitim uygulamaları. Açıkögretim Uygulamaları ve Araştırmaları Dergisi, 6(2), 11-53.

Chen, J. ve Simeonsson, R. J. (1994). Child disability and family needs in the people's Republic of China. International Journal of Rehabilitation Research, 17, 2537.

Doi: $10.1097 / 00004356-199403000-00003$

Cluver, L., Lachman, J. M., Sherr, L., Wessels, I., Krug, E., Rakotomalala, S., Blight, S., Hillis, S., Bachman, G., Green, O., Butchart, A., Tomlinson, M., Ward, C. L., Doubt, J. Ve McDonald, K. (2020). Parenting in a time of COVID-19. The Lancet, 395(10231), 1-4.

Doi: 10.1016/S0140-6736(20)30736-4

Colizzi, M. Sironi, E., Antonini, F., Ciceri, M. L., Bovo, C. ve Zoccante, L. (2020). Psychosocial and behavioral impact of COVID-19 in autism spectrum disorder: an online parent survey. Brain Sciences, 10(6), 1-14.

Creswell, J. W. ve Plano-Clark, V. L. (2011). Designing and conducting mixed methods research. Thousand Oaks, CA: Sage.

Çakın, M. ve Akyavuz, E. K. (2020). Covid-19 süreci ve eğitime yansıması: öğretmen görüşlerinin incelenmesi. International Journal of Social Sciences and Education Research, 6(2), 165-186.

Demirbilek, M. (2013). Zihinsel engelli bireylerin ve ailelerinin gereksinimleri. Turkish Journal of Family Medicine and Primary Care, 7(3), 58-64.

Den Houting, J. (2020). Stepping out of isolation: autistic people and COVID-19. Autism in Adulthood, 2(2), 103-105.

Devlet Personel Başkanlığı (2021). Kamu kurum ve kuruluşlarının personel alım ilanlarının devlet personel başkanlı̆̆ internet sitesinde yayımlanmasına dair tebliğ.

http://www.dpb.gov.tr/tr-tr

Di Carlo, F., Sociali, A., Picutti, E., Pettorruso, M., Vellante, F., Verrastro, V., Martinotti, G. ve Giannantonio, M. (2020). Telepsychiatry and other cutting edge technologies in Covid- 19 pandemic: Bridging the distance in mental health assistance. International Journal of Clinical Practice. 75(1), 1-9.

Doi: 10.22541/au.159007666.69069059

Drogomyretska, K., Fox, R. ve Colbert, D. (2020). Brief report: Stress and perceived social support in parents of children with ASD. Journal of Autism and Developmental Disorders, 50, 4176-4182.

Doi: 10.1007/s10803-020-04455-x 
Ercan, E. S., Arman, A., Emiroğlu, N., Öztop, D. B. ve Yalçın, Ö. (2020). COVID-19 (Korona) virüs salgını sırasında aile, çocuk ve ergenlere yönelik psikososyal ve ruhsal destek rehberi. Türkiye çocuk ve genç psikiyatrisi derneğii. https://www.ankara.edu.tr/wp-content/uploads/sites/6/2020/03/cogepdercovid-19rehberi30mart2020.pdf.pdf

Esentürk, O. K. (2020). Parents' perceptions on physical activity for their children with autism spectrum disorders during the novel Coronavirus outbreak. International Journal of Developmental Disabilities, (Online Print), 2047-3877. Doi: 10.1080/20473869.2020.1769333

Gören, A. B. (2015). Down sendromlu çocuğa sahip annelerin destek ihtiyaçlarının ve destek kaynaklarının belirlenmesi. Insan ve Toplum Bilimleri Araştırmaları Dergisi, 4(3), 651- 673.

Guralnick, M. J. (2011). Why early intervention works: A systems perspective. Infants and Young Children, 24, 6-28

Guralnick, M. J. ve Albertini, G. (2006). Early intervention in an international perspective. Journal of Policy and Practice in Intellectual Disabilities, 3(1), 1-2. Doi: 10.1111/j.1741-1130.2006.00046.x

Jalloh, M. F., Li, W., Bunnell, R. E., Ethier, K. A., O’Leary, A., Hageman, K. M., Sengeh, P., Jalloh, M. B. ve Morgan, O. (2018). Impact of Ebola experiences and risk perceptions on mental health in Sierra Leone, July 2015. BMJ Global Health, 3(2), 1-11.

Doi: 10.1136/bmjgh-2017-000471

Karahan, S., Demiröz, K., Yıldırım, Ş. ve Özaydın, L. (2020, Haziran). Kovid-19 sürecinde özel gereksinimli çocuklar ile çalışan öğretmenlerin gereksinimlerinin belirlenmesi. Uluslararsı Covid-19 Çalışmaları Konferansı'nda sunulan bildiri, Ankara, Çevrimiçi (Online) Kongre.

Kayhan, N. ve Özaydın, L. (2017). The quality of mainstreaming in preschool: The views of parents of children with down syndrome. Journal of Education and Learning, 7(2), 157-173.

Doi: $10.5539 /$ jel.v7n2p157

Kerem Günel, M. (2020). Covid-19 ve serebral palsili çocuklar. https://www.akademikakil.com/covid-19-ve-serebral-palsili cocuklar/mintazekeremgunel/

Lee, J. (2020). Mental health effects of school closures during COVID-19. The Lancet Child \& Adolescent Health, 4(6), 421.

Limbers, C. A., McCollum, C. ve Greenwood, E. (2020). Physical activity moderates the association between parenting stress and quality of life in working mothers during the COVID-19 pandemic. Mental Health and Physical Activity, 19, 17.

Majoko, T. ve Dudu, A. (2020). Parents' strategies for home educating their children with autism spectrum disorder during the COVID-19 period in Zimbabwe. International Journal of Developmental Disabilities, (Online Print), 1-5. Doi: 10.1080/20473869.2020.1803025

Manning, J., Billian, J., Matson, J. Allen, C. ve Neelkamal Soares, N. (2020). Perceptions of families of individuals with autism spectrum disorder during the COVID-19 crisis. Journal of Autism and Developmental Disorders, (Online Print), 1-9.

Doi: $10.1007 / \mathrm{s} 10803-020-04760-5$ 
Marchetti, D., Fontanesi, L., Mazza, C., DiGiandomenico, S., Roma, P. ve Verrocchio, M. C. (2020). Parenting-related exhaustion during the Italian COVID19 lockdown. Journal of Pediatric Psychology, 45, 1114-1123.

Milli Eğitim Bakanlığı (2018). Özel eğitim hizmetleri yönetmeliği. https://orgm.meb.gov.tr/www/ozelegitimhizmetleriyönetmeligiyayimlandi/icerik/1089

Narzisi, A. (2020). Handle the autism spectrum condition during Coronavirus (COVID-19) stay at home period: Ten tips for helping parents and caregivers of young children. Brain Sciences, 10(4), 1-4.

Doi: 10.3390/brainsci10040207

Neece, C., Mcintyre L. L. ve Fenning, R. (2020). Examining the impact of COVID19 in ethnically diverse families with young children with intellectual and developmental disabilities. Journal of Intellectual Disability Research, 64, 739749.

Özaydın, L. (2020a). Koronavirüs sürecinde özel gereksinimli çocukların eğitimi ve aileler.

https:/www.setav.org/5-soru-koronavirus-surecinde-ozel-gereksinimli-cocuklarin-egitimi-ve-aileler/

Özaydın, L. (2020b). Kaynaştırma uygulamalarında öğretmen yardımcısının görevlerine ilişkin paydaş görüşleri: Karma yöntem çalışması. Ankara Üniversitesi Eğitim Bilimleri Fakültesi Özel Eğitim Dergisi, 21(3), 561-587.

Doi: 10.21565/ozelegitimdergisi.563242

Özaydın, L. ve Usak, E. (2014). Expectations of parents from sportive and physical activities for their child with autism and their views over autism friendly environment. Journal of Environmental Protection and Ecology, 15(3), 1493-1506.

Pavlopoulou, G., Wood, R. ve Papadopoulos, C. (2020). Impact of Covid-19 on the experiences of parents and family carers of autistic children and young people in the UK.

https://discovery.ucl.ac.uk/id/eprint/10101297/3/Pavlopoulou_COVID19\%20AUTISM\%20FINAL\%20GP.pdf

Toseeb, U., Asbury, K., Code, A., Fox, L. ve Deniz, E. (2020). Supporting families with children with special educational needs and disabilities during COVID19.

https://psyarxiv.com/tm69k/

Toy, A. ve Kesici, İ. (2020). Özel gereksinimli çocuğu olan annelerin eğitim ihtiyaçlar1. Journal of Advanced Education Studies, 2(1), 61-93. https://dergipark.org.tr/en/pub/ejaes/issue/54791/698811

Turan-Gürhopur, F. D. ve İşler-Dalgıç, A. (2017). Zihinsel yetersiz çocuğu olan ebeveynlerde aile yükü. Psikiyatri Hemşireliği Dergisi, 8(1), 9-16.

Türkiye İstatistik Kurumu [TÜİK] (2010). Özürlülerin sorun ve beklentileri araştırmasl.

https://ailevecalisma.gov.tr/media/5602/ozurlulerin-sorun-ve-beklentileriarastirmasi-2010.pdf

UNICEF (2020). COVID-19 bağlamında aile dostu politikalar ve diğer iyi işyeri uygulamalart: İşverenlerin atabileceği önemli adımlar. https://www.ilo.org/wcmsp5/groups/public/---europe/---ro-geneva/---ilo-ankara/documents/publication/wcms_741797.pdf 
Wigg, C. M. D., Coutinho, I. M. F. de A., da Silva, I. C. ve Lopes, L. B. (2020). The mental health of children and adolescents during the COVID-19 pandemic: a narrative review. Research, Society and Development, 9(9), e704997687e704997687.

Doi: $10.33448 /$ rsd-v9i9.7687

Witt, A., Ordóñez, A., Martin, A., Vitiello, B. ve Fegert, J. M. (2020). Child and adolescent mental health service provision and research during the Covid-19 pandemic: challenges, opportunities, and a call for submissions. Child and Adolescent Psychiatry and Mental Health, 14(19), 1-4.

Doi: 10.1186/s13034-020-00324-8

World Health Organization (2020). Mental health and psychosocial considerations during the COVID-19 outbreak.

https://www.who.int/docs/default-source/coronaviruse/mental-health-considerations.pdf.

Yarımkaya, E. ve Esenturk, O. K. (2020). Promoting physical activity for children with autism spectrum disorders during coronavirus outbreak: benefits, strategies, and examples. International Journal of Developmental Disabilities, (Online Print), 1-6.

Yazıcı, D. N ve Durmuşoğlu, M. C. (2017). Özel gereksinimli çocuğu olan ailelerin karşılaştığ 1 sorunlar ve beklentilerinin incelenmesi. Uludă̆ Üniversitesi Ĕgitim Fakültesi Dergisi, 30(2), 657-681.

Yıldırım, A. ve Şimşek, H. (2018). Sosyal bilimlerde nitel araştırma yöntemleri (11. bask1). Ankara: Seçkin Yayınevi.

Yıldırım, Ş. ve Hacıfazlıoğlu, Ö. (2019, Kasım). OSB tanısı almış çocuğu olan çalışan annelerin iş ve yaşam dengeleri. 29. Ulusal Özel Eğitim Kongresi'nde sunulan bildiri, Kuşadası, İzmir.

Yılmaz, E., Mutlu, H. ve Doğanay, G. (2020). Veli algısına göre pandemi dönemi uzaktan eğitim sürecinin niteliği.

http://paletyayinlari.com.tr/wpcontent/uploads/2020/Uzaktan_egitim_surecinin_niteligi.pdf (Erişim tarihi: 06.06.2020) 